\title{
The Influence of Zeolitic By-Product Containing Ammonium Ions on Properties of Hardened Cement Paste
}

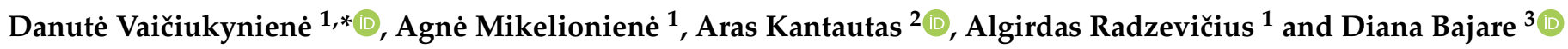 \\ 1 Faculty of Water and Land Management Agriculture Academy, Vytautas Magnus University, Studentu st. 11, \\ LT-53361 Akademija, Lithuania; agne.mikelioniene@gmail.com (A.M.); algirdas.radzevicius@vdu.lt (A.R.) \\ 2 Faculty of Civil Engineering and Architecture, Kaunas University of Technology, Studentu st. 48, \\ LT-51367 Kaunas, Lithuania; aras.kantautas@ktu.lt \\ 3 Faculty of Civil Engineering, Department of Building Materials and Products, Riga Technical University, \\ Kalku st. 1, LV-1658 Riga, Latvia; diana.bajare@rtu.lv \\ * Correspondence: danute.vaiciukyniene@ktu.lt; Tel.: +370-657-66-815
}

Citation: Vaičiukynienè, D.; Mikelionienè, A.; Kantautas, A.; Radzevičius, A.; Bajare, D. The Influence of Zeolitic By-Product Containing Ammonium Ions on Properties of Hardened Cement Paste. Minerals 2021, 11, 123. https:// doi.org/10.3390/min11020123

Received: 17 December 2020

Accepted: 21 January 2021

Published: 27 January 2021

Publisher's Note: MDPI stays neutral with regard to jurisdictional claims in published maps and institutional affiliations.

Copyright: (c) 2021 by the authors. Licensee MDPI, Basel, Switzerland. This article is an open access article distributed under the terms and conditions of the Creative Commons Attribution (CC BY) license (https:// creativecommons.org/licenses/by/ $4.0 /)$.

\begin{abstract}
Fluid catalytic cracking (FCC) catalysts, used in the petroleum industry, are sources of zeolitic by-products. These by-products are often used as sorbents for the removal of ammonium ions from wastewater. After a period of use, the zeolitic by-product loses its sorption properties and is no longer effective. The problem is the use of zeolitic by-product with ammonium ions. In this study, a zeolitic by-product containing ammonium ions and high contents of active $\mathrm{SiO}_{2}$ and $\mathrm{Al}_{2} \mathrm{O}_{3}$ was used as a supplementary cementitious material (SCM). Cement pastes containing $0.5 \%, 1 \%, 3 \%$, $5 \%$, and $10 \%$ of the by-product were prepared, and the compressive strength and density of the pastes were evaluated. Incorporation of the zeolitic by-product increased the cement strength by $17 \%$ and $32 \%$ after 7 and 28 days of hydration, respectively. Thus, incorporation of the zeolitic by-product with ammonium ions as an SCM has a complex effect on an ordinary Portland cement (OPC) system. Ammonium chloride accelerated cement setting after 7 days of hydration, and the pozzolanic reaction positively affected strength development after 28 days of hydration. The reaction products caused the cement to have a compact microstructure. The zeolitic by-product containing absorbed ammonium ions can be successfully reused to replace ordinary Portland cement in cement pastes.
\end{abstract}

Keywords: fluid catalytic cracking (FCC) catalysts; zeolitic by-product; Portland cement hydration

\section{Introduction}

Supplementary cementitious materials (SCMs) are often used in low-carbon cement blends. SCMs are environmentally friendly and can improve basic concrete properties. Concrete that contains SCMs exhibits a higher resistance to chloride ingress, the alkali-silica reaction, freeze-thaw damage, and sulfate attack [1]. Rahla et al. [2] investigated binary concrete blends containing fly ash, ground granulated blast-furnace slag, and silica fume. The most sustainable blended concretes contained no more than $40 \%$ of ground granulated blast-furnace slag, $5 \%$ of silica fume, and $20 \%$ of fly ash, according to Rahla et al. [2]. Zhao et al. [3] reported that the incorporation of quarry dust increased the early compressive strength of slag cement. This increase could be attributed to the filler effect. Incorporating up to $20 \%$ quarry dust did not significantly change the compressive strength after 28 days. SCMs have different sources and physical and chemical properties. SCMs significantly affect the basic properties of concrete and the hydration process of cement pastes. Lu et al. [4] investigated the influence of supplementary materials, such as silica fume, fly ash, and blast furnace slag, on the autogenous shrinkage of Portland cement pastes. The autogenous shrinkage of Portland cement paste was decreased by the inclusion of fly ash, not significantly changed by the inclusion of silica fume, and significantly increased by the inclusion of blast furnace slag. The autogenous shrinkage is closely related to the additional internal curing water. It is important to use the special additives of concrete 
that could accumulate (absorb) water; one of these materials could be zeolites. During mixing, zeolite absorbs water; after that, during the hydration process, it gradually releases the absorbed water. Therefore, the incorporation of zeolite could have a double effect on the hydration of concrete. First, additional internal curing water could decrease the autogenous shrinkage and promote cement hydration later. Second, zeolites could improve the mechanical properties of concrete due to a pozzolanic reaction. Lv et al. [5] used natural zeolite in cement systems and determined that the incorporation of $20 \%$ natural zeolite reduced the autogenous shrinkage. The addition of zeolite reduced the autogenous shrinkage of high-performance or ultra-high-performance cement-based concrete $[4,6,7]$. The experiments were based on the substitution of cement with zeolite (up to $15 \%$ ) or on the replacement of standard sands with zeolite sands (15\% and $30 \%)$.

A wide variety of studies were conducted on the use of zeolitic materials in Portland cement systems. Natural pozzolans were used as natural zeolites. Nagrockiene et al. [8] determined that incorporating up to $10 \%$ clinoptilolite in concrete increased the compressive strength, reduced the water absorption by 2.3 times, and increased the density and ultrasonic pulse velocity. Blends of Portland cement and clinoptilolite were investigated in a different study. The strength development that resulted from a pozzolanic reaction of the zeolite after 28 days of hydration was determined. The early compressive strength of the concrete containing the zeolite was lower than that of samples without zeolite. However, the compressive strength increased after 28 days of hydration, as reported by Rahhal et al. [9]. The addition of clinoptilolite, silica fume, and fly ash in the cement systems were investigated by Lilkov et al. [10]. They determined that the optimal amount of clinoptilolite was $10 \%$ with a mixture of $10 \%$ silica fume and fly ash. The incorporation of this complex addition showed an increase of $8 \%$ in flexural strength and $13 \%$ in compressive strength compared to samples without any pozzolanic additives. This increase in strength is closely related to the large surface area of the particles at the early age of hydration. At a later age of hydration, pozzolanic reactions occur between the products of cement hydration and zeolites [11]. Girskas et al. [12] analyzed how the inclusion of synthetic zeolites affected the properties of concrete. A zeolite was synthesized from a silica by-product. Inclusion of up to $10 \mathrm{wt} \%$ of the zeolitic material increased the concrete's durability.

Fluid catalytic cracking (FCC) catalysts are by-products of the petroleum industry. After a period of use, these materials do not retain sufficient catalytic activity for FCC and become zeolitic by-products. Most zeolitic by-products are disposed of in landfills. Blends of FCC catalysts and ordinary Portland cement have been studied. Da et al. [13] investigated the effects of incorporating spent petroleum-refining catalysts into cement. The addition of $0.5 \%$ spent petroleum-refining catalysts increased the early strength and accelerated the setting time of the cement. The addition of a higher quantity of the catalyst $(5.0 \%)$ increased the early strength of the cement. Allahverdi et al. [14] found that incorporating residual fluid catalytic cracking units into cement significantly increased the compressive strength because of a pozzolanic reaction, but it lowered the sulfate resistance in a highly aggressive sulfate environment to below that of Portland cement samples. Additionally, increasing the quantity of spent FCC increased the quantity of water required because of the high porosity of spent FCC, as reported by Su et al. [15]. Incorporating up to $15 \mathrm{wt} \%$ of spent FCC increased the compressive strength of concrete samples, whereas higher spent FCC contents negatively impacted strength development.

Zeolites are good sorbents for municipal and industrial pollution control. Numerous studies have been published on using natural or synthetic zeolites to remove ammonium ions from water [16-19]. Fu et al. [16] performed natural zeolite modification with impregnation of $\mathrm{NaNO}_{3}$; after that, it was calcined. After the modification process, the average pore size of zeolites increased; this factor had a positive influence on the ammonium sorption properties. Ammonium removal was at $81.68 \%$ for the modified zeolite compared to the unmodified zeolite, whose removal reached $41.80 \%$. Kotoulas et al. [19] used natural zeolite, based on clinoptilolite, for the removal of ammonium from wastewater. During 
column experiments, the ammonium removal reached over $96 \%$ after 120 min when initial concentrations were 200 and $5000 \mathrm{mg} / \mathrm{L}$.

Several studies have been performed on the effects of ammonium compounds on the hydration of Portland cement. Qin et al. [20] investigated the influence of coal fly ash containing ammonium salts on the properties of cement paste. The incorporation of ammonium salts $\left(\mathrm{NH}_{3} \mathrm{HSO}_{4}\right.$ or $\left.\left(\mathrm{NH}_{3}\right)_{2} \mathrm{SO}_{4}\right)$ negatively affected the strength, early age hydration, and microstructure of cement pastes. Different results were obtained by adding $\mathrm{NH}_{4} \mathrm{Cl}$ to cement. $\mathrm{NH}_{4} \mathrm{Cl}$ accelerated cement setting due to the reaction of ammonium chloride with portlandite [21-24]. This accelerator significantly increased concrete strength development. Ammonium chloride was used as a cement-setting accelerator in composite materials based on Portland cement reinforced with wood waste. Myrdal et al. [22] reported that $\mathrm{NH}_{4} \mathrm{Cl}$ is a highly effective admixture for lignocellulose composite materials. Frybort et al. $[23,24]$ reported that $\mathrm{NH}_{4} \mathrm{Cl}$ addition positively affected concrete properties. The addition of $\mathrm{NH}_{4} \mathrm{Cl}$ improved the mechanical properties of cement-bonded composites at early ages but decreased their ultimate strength.

In this study, we investigated the effect of a zeolitic by-product containing ammonium ions on the properties of hardened cement paste. The paper explains the artificial waste materials, based on faujasite, that can be used as supplementary cementitious materials. We aimed to demonstrate the possibility of using these zeolitic by-products containing ammonium ions by evaluating their main properties. The outcome of this study is the use of zeolitic by-products with ammonium ions, which occur after ammonium sorption.

\section{Methods and Materials}

The chemical composition of a zeolitic waste was determined using an X-ray fluorescence spectrometer (Bruker X-ray S8 Tiger WD) using a rhodium (Rh) tube, an anode voltage $\left(\mathrm{U}_{\mathrm{a}}\right)$ up to $60 \mathrm{kV}$, and an electric current (I) up to $130 \mathrm{~mA}$. Pressed samples were analyzed in a helium atmosphere. Measurements were performed using the SPECTRA Plus QUANT EXPRESS method [25].

An X-ray diffraction analysis of the materials was performed using a D8 Advance diffractometer (Bruker AXS) operating at a tube voltage of $40 \mathrm{kV}$ and a tube current of $40 \mathrm{~mA}$. The X-ray beam was filtered with an Ni $0.02 \mathrm{~mm}$ filter to select the $\mathrm{CuK} \alpha$ wavelength. The specimens were scanned over a $2 \theta$ range of $3-70^{\circ}$ at a scanning speed of $6^{\circ} \mathrm{min}^{-1}$, with a coupled two theta/theta scan type [26].

The particle size distribution of the zeolitic by-product was determined by using a laser particle size analyzer (CILAS 1090 LD). The distribution of solid particles in the air stream was $12-15 \mathrm{wt} \%$. Compressed air ( $2500 \mathrm{mbar}$ ) was used as the dispersing phase. The measurement time was $15 \mathrm{~s}$ [27]. The specific surface was measured with a Blaine instrument, according to the EN 196-6:2010 standard. Bulk density is the mass of powder in a given volume. Specific density is the particle density based on the particle volume, excluding all internal pores which are connected to the surrounding air space.

The microstructures of the zeolitic by-product and hardened cement pastes were studied by scanning electron microscopy. Any special sample preparations (polishing or the use of covering materials) were not used. Before the SEM analysis, the samples were fresh splinted only. A high-resolution scanning electron microscope (ZEISS EVO MA10) was used [28].

The hydration temperatures of pastes were measured according to the semi-adiabatic method. An 8-channel USB TC-08 thermocouple data logger of K type was used. The temperature measurements ranged from -270 to $+1820^{\circ} \mathrm{C}$.

The cement paste samples were based on ordinary Portland cement (OPC). The commercial Portland cement, type CEM I 52.5R, was used. The OPC chemical composition is shown in Table 1. The zeolitic by-product with ammonium ions was incorporated as a supplementary cementitious material (SCM) into the cement paste systems. In our previous study, this zeolitic by-product was used as a sorbent for ammonium ions [29]. After a period of use, this zeolitic by-product loses its sorption properties and is no longer effective. 
After the sorption process, the zeolitic by-product were separated from solution and dried at $60{ }^{\circ} \mathrm{C}$. Thereafter, the zeolitic by-product was found to contain $3.87 \% \mathrm{NH}_{4} \mathrm{Cl}$, based on the chlorine content (Table 1). It is possible that there could be an additional amount of $\mathrm{NH}_{4}{ }^{+}$in the zeolitic by-product. The water-to-binder ratio (W/B) of the cement paste was 0.36 . The chemical composition (Table 1) shows that the zeolitic by-product was rich in silica and aluminum oxides.

Table 1. Chemical composition of ordinary Portland cement and zeolitic by-product, \% (by X-ray fluorescence (XRF) analysis.

\begin{tabular}{ccc}
\hline Parameter & Portland Cement CEM I 52.5R & Zeolitic By-Product \\
\hline $\mathrm{SiO}_{2}$ & 21.00 & 35.4 \\
$\mathrm{Al}_{2} \mathrm{O}_{3}$ & 3.90 & 48.77 \\
$\mathrm{Fe}_{2} \mathrm{O}_{3}$ & 2.90 & 1.02 \\
$\mathrm{La}_{2} \mathrm{O}_{3}$ & - & 1.63 \\
$\mathrm{TiO}_{2}$ & - & 3.57 \\
$\mathrm{MgO}$ & 2.70 & 0.44 \\
$\mathrm{CaO}$ & 66.00 & 0.37 \\
$\mathrm{Na}_{2} \mathrm{O}$ & - & 0.312 \\
$\mathrm{SO}_{3}$ & 3.40 & 0.07 \\
$\mathrm{P}_{2} \mathrm{O}_{5}$ & - & 0.08 \\
$\mathrm{~K}_{2} \mathrm{O}$ & - & - \\
$\mathrm{Cl}$ & 0.06 & 2.57 \\
Other & - & 5.77 \\
Bulk density, $\mathrm{kg} / \mathrm{m}^{3}$ & 1236 & 864 \\
Specific density, kg/m & 3122 & 2679 \\
Surface area (by Blaine), $\mathrm{m}^{2} / \mathrm{g}$ & 350.0 & 142.1 \\
\hline
\end{tabular}

The mineral composition of the zeolitic by-product was evaluated by XRD (Figure 1a). The material was predominantly a faujasite type zeolite [15].

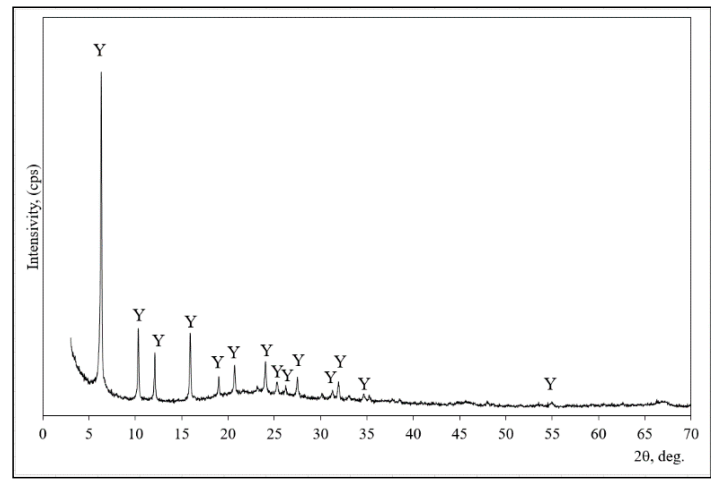

(a)

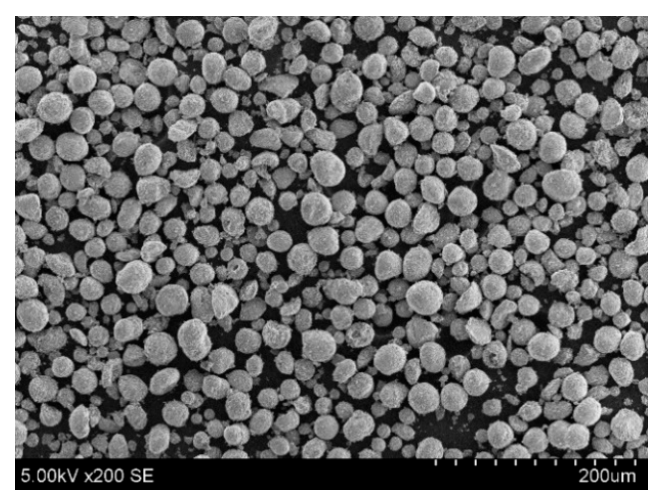

(b)

Figure 1. X-ray diffraction pattern of zeolitic by-product with ammonium chloride (a) and SEM micrographs (b), where Y is faujasite (73-2312) $\mathrm{H}_{7.7} \mathrm{Al}_{42.56} \cdot \mathrm{Si}_{139} \cdot \mathrm{O}_{345.6} \cdot$ zeolite type.

The zeolitic by-product microstructure consisted of spherical particles (Figure 1b). Velázquez et al. [30] found similarly shaped zeolitic by-product particles.

Figure 2 shows the particle size distributions for the zeolitic by-product and OPC used in this study. The zeolitic by-product exhibited a peak from 16 to $280 \mu \mathrm{m}$ (Figure 3a). The OPC particle sizes were distributed from 0.05 to $52.5 \mu \mathrm{m}$ (Figure 3b). Two peaks in the distribution histogram were observed: at $1.8 \mu \mathrm{m}$ (1.75\% of all particles) and at $19.42 \mu \mathrm{m}$ ( $2.14 \%$ of all particles). We determined that finer particles dominated the OPC when compared to the curve for the zeolitic by-product. The surface area results (Table 1) show that the particles of zeolitic by-product were almost 2.5 times coarser than the Portland cement particles (Table 1). 


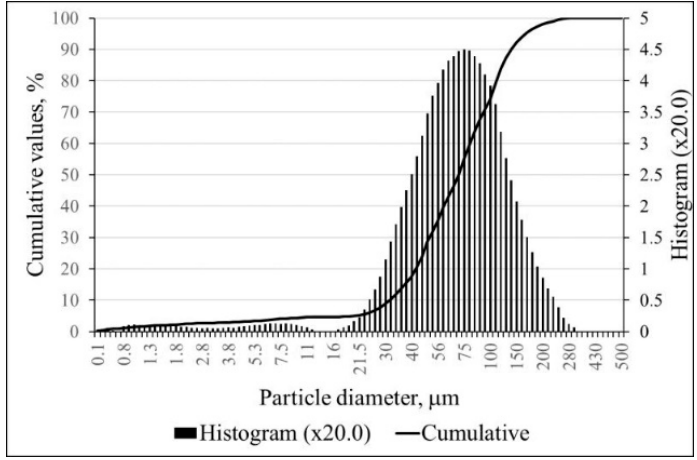

(a)

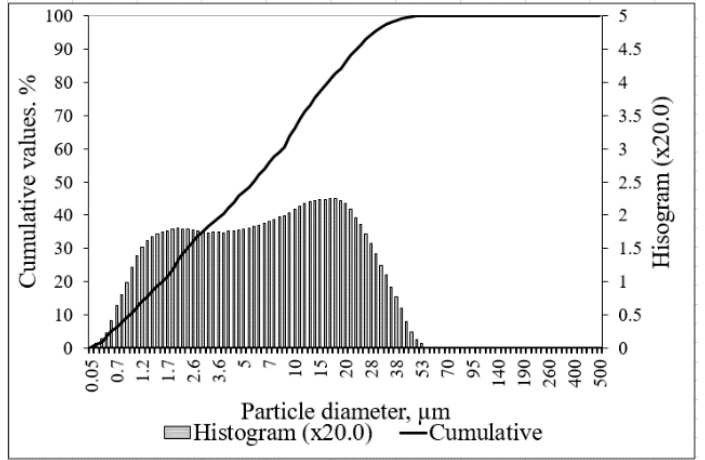

(b)

Figure 2. Particle size distributions of zeolitic by-product with ammonium chloride (a) and Portland cement (b).

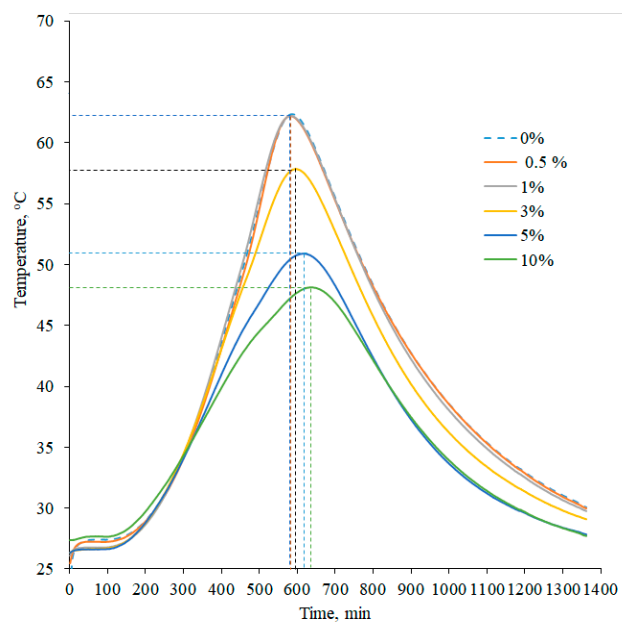

(a)

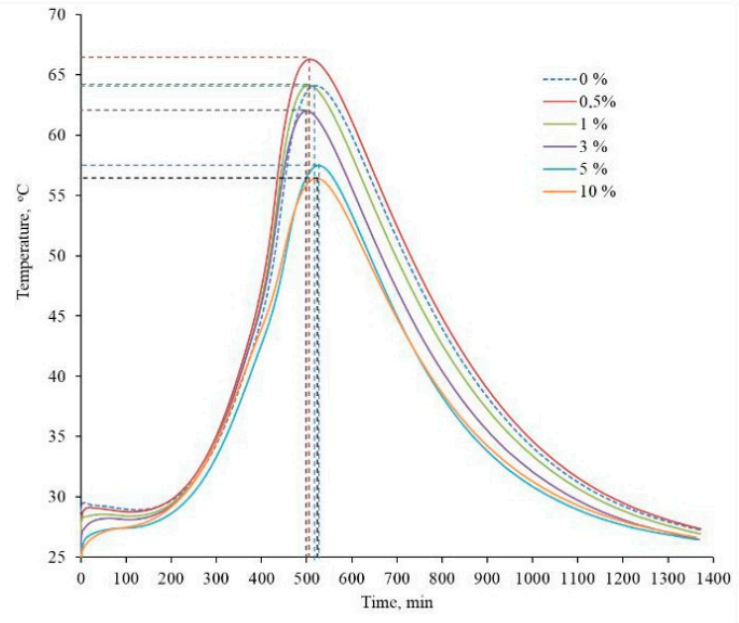

(b)

Figure 3. Effect of zeolitic by-product on hydration temperature of Portland cement pastes containing different amounts of zeolitic by-product: (a) the zeolitic by-product without ammonium ions and (b) the zeolitic by-product with ammonium ions.

The composition of the initial cement pastes is shown in Table 2. Five types of cement pastes were prepared. Reference samples were made from OPC powder and water only. The zeolitic by-product with ammonium chloride was used to replace a portion of the OPC in the remaining samples. The same ratio of water-to-solid materials was used in all the samples.

Table 2. Compositions of initial mixtures.

\begin{tabular}{cccc}
\hline Samples & $\begin{array}{c}\text { Ordinary Portland } \\
\text { Cement (wt\%) }\end{array}$ & $\begin{array}{c}\text { Zeolitic By-Product } \\
\text { with Ammonium } \\
\text { Chloride (wt\%) }\end{array}$ & $\begin{array}{c}\text { Water-to-Solid } \\
\text { Materials Ratio } \\
\text { (W/S) }\end{array}$ \\
\hline Reference & 100 & 0 & 0.36 \\
S0.5 & 99.5 & 0.5 & 0.36 \\
S1 & 99.0 & 1.0 & 0.36 \\
S3 & 97.0 & 3.0 & 0.36 \\
S5 & 95.0 & 5.0 & 0.36 \\
S10 & 90.0 & 10.0 & 0.36 \\
\hline
\end{tabular}


The OPC paste samples $(2 \mathrm{~cm} \times 2 \mathrm{~cm} \times 2 \mathrm{~cm}$ size cubes) were cured for 7 and 28 days, after which the compressive strength and the density were determined. An automated and computerized ToniTechnik 2020 press was used to evaluate the compression strength of the hardened cement paste. Each the compressive strength and the density value were the average of six samples.

\section{Results}

The hydration temperatures of the cement pastes with different OPC substitutions with zeolitic by-product without ammonium ions are shown in Figure 3a. The results showed that the incorporation of the zeolitic by-product gradually delayed the hydration process; this delay was more significant when increasing the amount of zeolitic by-product in the system. Thus, the hydration temperature depended on the amount of zeolitic byproduct. By increasing the amount of zeolitic by-product, the main peak of hydration temperature decreased, and this decrease could be related to the dilution effect. García et al. [31] reported similar results.

Incorporating the zeolitic by-product with ammonium ions into the OPC samples significantly changed the hydration temperature (Figure $3 b$ ). In the zeolitic by-product, ammonium ions exchanged with the hydrogen ions, according to the reaction Equation (1):

$$
\text { Zeolitic by-product }-\mathrm{H}_{3} \mathrm{O}^{+}+\mathrm{nNH}_{4}{ }^{+}=\text {Zeolitic by-product }-\mathrm{nNH}_{4}{ }^{+}+\mathrm{H}_{3} \mathrm{O}
$$

where $\mathrm{H}$ represents exchangeable ions in zeolite and $\mathrm{n}$ is the number of electric charges [32].

Low substitutions (0.5-3 wt\%) of OPC with the zeolitic by-product slightly accelerated the hydration process. Peak times of 515, 512, and 504 min were obtained for samples containing $0.5 \%, 1 \%$, and $3 \%$ of the zeolitic by-product, respectively, whereas the reference sample had a peak time of $518 \mathrm{~min}$. This result could be attributed to the cement setting acceleration of ammonium chloride [33]. High zeolitic by-product contents (5 and $10 \mathrm{wt} \%$ ) slightly delayed the hydration process. This slowdown in hydration could be related to the dilution effect.

The main hydration peak temperature $\left(66.2^{\circ} \mathrm{C}\right)$ of the sample containing $0.5 \%$ of the zeolitic by-product was slightly higher than the hydration temperature $\left(64.0^{\circ} \mathrm{C}\right)$ of the reference sample containing $0 \%$. Almost the same temperatures were reached for the sample containing $1 \%$ of the zeolitic by-product. Thus, increasing the zeolitic by-product content gradually decreased the main hydration peak temperature of the samples. This decrease was attributed to binder dilution [34].

Perraki et al. [35] reported three factors influencing the strength of blended cements: the filler, the dilution, and the pozzolanic reaction. Figure 4a shows how the compressive strength of the hardened cement paste samples developed for different contents of the zeolitic by-product containing ammonium ions. We previously determined [36] that substituting cement with the zeolitic by-product slightly decreased the compressive strength after 7 days. Increasing the substitution level gradually decreased the compressive strength. Similar strength results were reported [37]. This decrease at 7 days could be related to the dilution effect. In the present study, the strengths of all the pastes containing the zeolitic by-product with ammonium ions were higher than those of the reference sample at 7 days of hydration. It is possible that ammonium chloride, which releases from zeolitic by-product during the hydration process, acted as a cement-setting accelerator $[33,34]$.

During cement hydration, ammonium chloride reacted with portlandite, according to the reaction in Equation (2):

$$
\mathrm{Ca}(\mathrm{OH})_{2}+2 \mathrm{NH}_{4} \mathrm{Cl}=\mathrm{CaCl}_{2}+2 \mathrm{NH}_{3}+2 \mathrm{H}_{2} \mathrm{O}
$$

The formed calcium chloride is widely used for the acceleration of early cement hydration [38]. Thus, using the zeolitic by-product with ammonium chloride as an accelerator increased the cement strength after 7 days. The highest compressive strength, $84 \mathrm{MPa}$, was 
obtained using $3 \%$ of the zeolitic by-product, whereas the reference sample exhibited a compressive strength of $72 \mathrm{MPa}$.

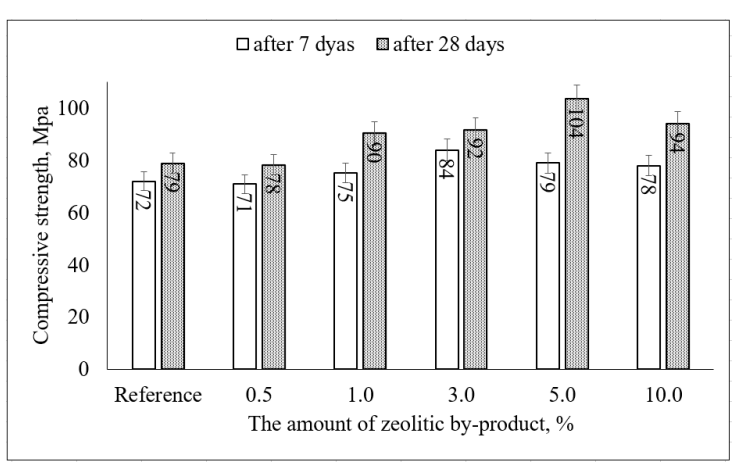

(a)

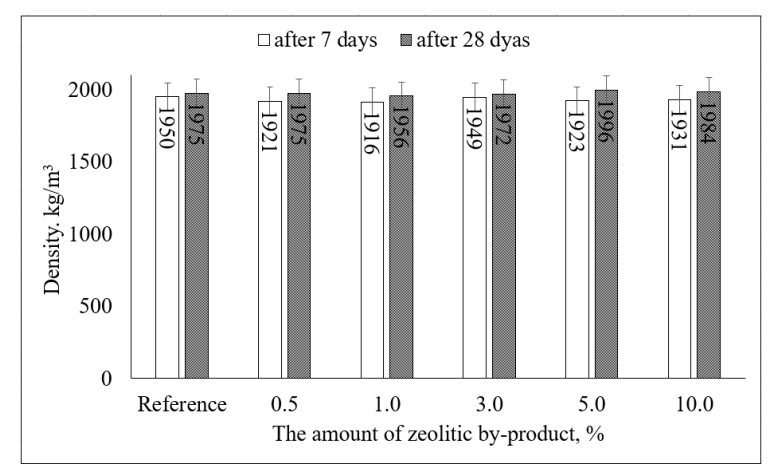

(b)

Figure 4. Compressive strength (a) and density (b) of hardened cement paste samples containing different amounts of zeolitic by-product.

The clear increase in the sample strength after 28 days mainly resulted from the pozzolanic reaction of the zeolitic by-product. All the investigated samples exhibited higher compressive strengths than the reference sample. The compressive strength of the samples increased with the zeolitic by-product content up to $5 \mathrm{wt} \%$ and then slightly decreased. A compressive strength of $104 \mathrm{MPa}$ was obtained for the sample containing $5 \mathrm{wt} \%$ of the zeolitic by-product.

Thus, using the zeolitic by-product with ammonium ions as a SCM has a complex effect in an OPC system. After 7 days of hydration, ammonium chloride acted as a cementsetting accelerator, and after 28 days of hydration, the pozzolanic reaction positively affected strength development. Similar results were reported by Lothenbach et al. [39].

The density of samples was similar (Figure 4 b) and slightly decreased as the zeolitic by-product content increased. The sample density after 28 days of hydration was higher than that after 7 days of hydration.

The mineral composition was evaluated from X-ray diffraction patterns (Figure 5). Ettringite, portlandite, calcium silicate hydrate, and calcite were identified as the main OPC hydration products. Any peaks assigned to faujasite zeolites were not detected. Therefore, zeolitic by-products transformed to calcium silicate hydrate and calcium aluminate/silicate hydrate in the alkaline environmental of cement paste [40]. All three curves exhibited the same peaks, albeit with slightly different intensities. Incorporating the zeolitic by-product into cement enhanced the ettringite peak intensity. The zeolitic by-product formed an additional hydration product-calcium hemicarboaluminate hydrate. This hydrate formed only in the S5 sample and could be related to the incorporation of zeolitic by-product. When this by-product is incorporated into a Portland cement paste in a high $\mathrm{pH}$ solution, the aluminosilicate network is broken and depolymerized species enter the solution. $\mathrm{Ca}^{2+}$ ions reacted with aluminate species, and calcium hemicarboaluminate hydrate formed. The higher compressive strength of the samples containing the zeolitic by-product compared to that of the reference sample was attributed to these additional hydration products (Figure 4), which have the tendency to harden and develop mechanical strength [34].

An FTIR analysis was performed on the sample with the highest compressive strength and the reference sample (Figure 6). The middle infrared region of $400-4000 \mathrm{~cm}^{-1}$ was used as the test range. The FTIR spectra of the samples exhibited the same peaks but with different intensities. The first two peaks, at approximately 3460 and $1652 \mathrm{~cm}^{-1}$, were assigned to the stretching vibration of $-\mathrm{OH}$ and the bending vibration of $\mathrm{O}-\mathrm{H}-\mathrm{O}$, respectively. The first peak at approximately $3460 \mathrm{~cm}^{-1}$ is related to the symmetric and antisymmetric stretching vibration of water bound in the cement hydration products [41]. 
The carbonate bands (the vibrations of $\mathrm{CO}_{3}{ }^{2-}$ ) at approximately 1454 and $866 \mathrm{~cm}^{-1}$ are associated with C-O stretching [42].

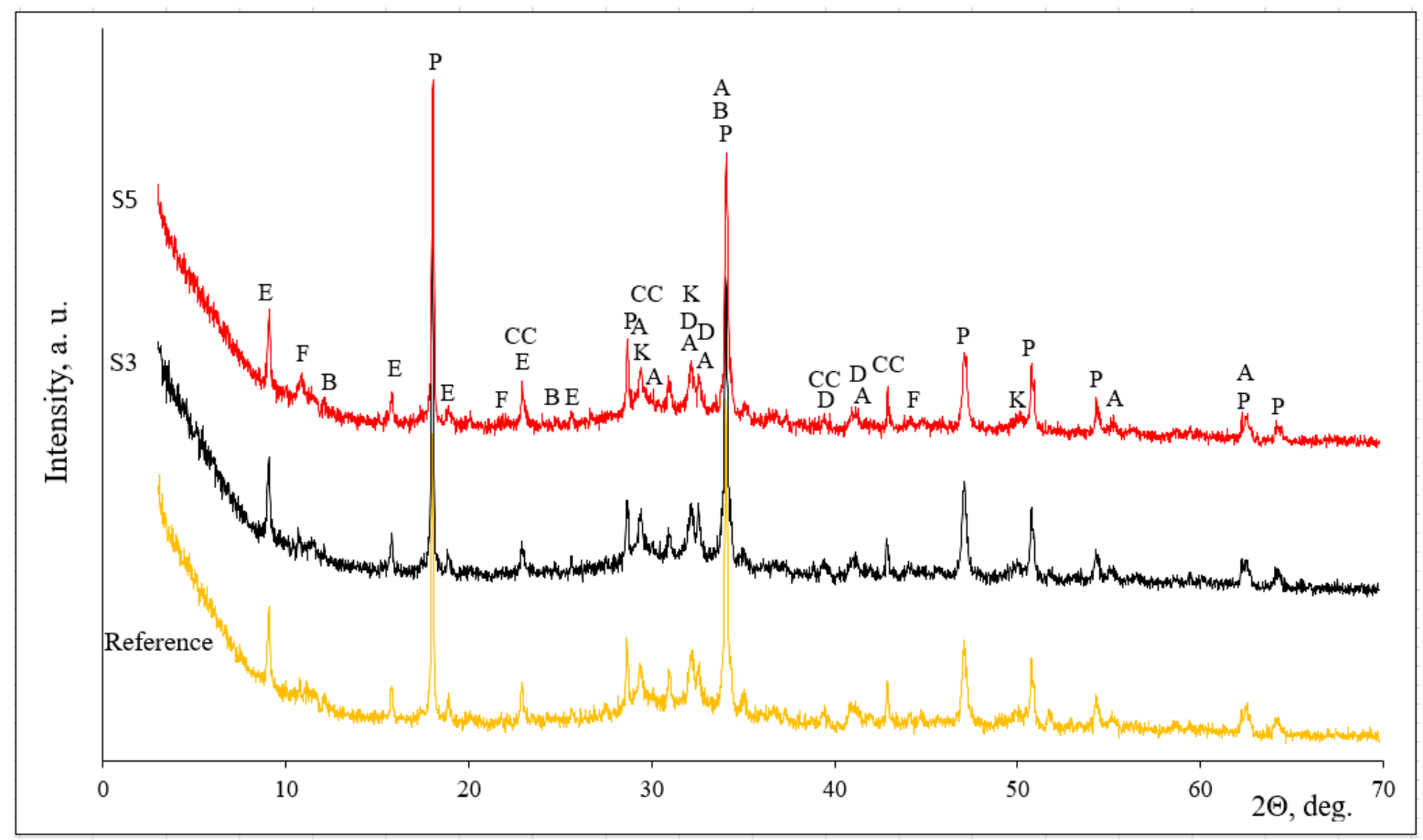

Figure 5. X-ray diffraction patterns of hardened cement paste samples containing the zeolitic by-product after 28 days of hydration: E-ettringite $\mathrm{Ca}_{6} \mathrm{~A}_{12}\left(\mathrm{SO}_{4}\right)_{3}(\mathrm{OH})_{12} \cdot 26 \mathrm{H}_{2} \mathrm{O}$ (41-1451), $\mathrm{P}$ - portlandite $\mathrm{Ca}(\mathrm{OH})_{2}(44-1481), \mathrm{A}-\mathrm{Ca}_{54} \mathrm{MgA}_{12} \mathrm{Si}_{16} \mathrm{O}_{90}$ (13-272), D-larnite $\mathrm{Ca}_{2}\left(\mathrm{SiO}_{4}\right)$ (83-461), $\mathrm{K}$-calcium silicate hydrate $\mathrm{Ca}_{1} \cdot 5 \mathrm{Si} \mathrm{O}_{3 \cdot 5} \cdot \mathrm{H}_{2} \mathrm{O}(33-306), \mathrm{CC}$-calcite CaCO 3 (72-1651), $\mathrm{F}$-calcium hemicarboaluminate hydrate $\mathrm{Ca}_{4} \mathrm{Al}_{2} \mathrm{O}_{6}\left(\mathrm{CO}_{3}\right)_{0 \cdot 5}(\mathrm{OH}) \cdot 11.5 \mathrm{H}_{2} \mathrm{O}(41-221)$, and $\mathrm{B}$-brownmillerite $\mathrm{Ca}_{2}(\mathrm{Al}, \mathrm{Fe})_{2} \mathrm{O}_{5}(30-226)$.

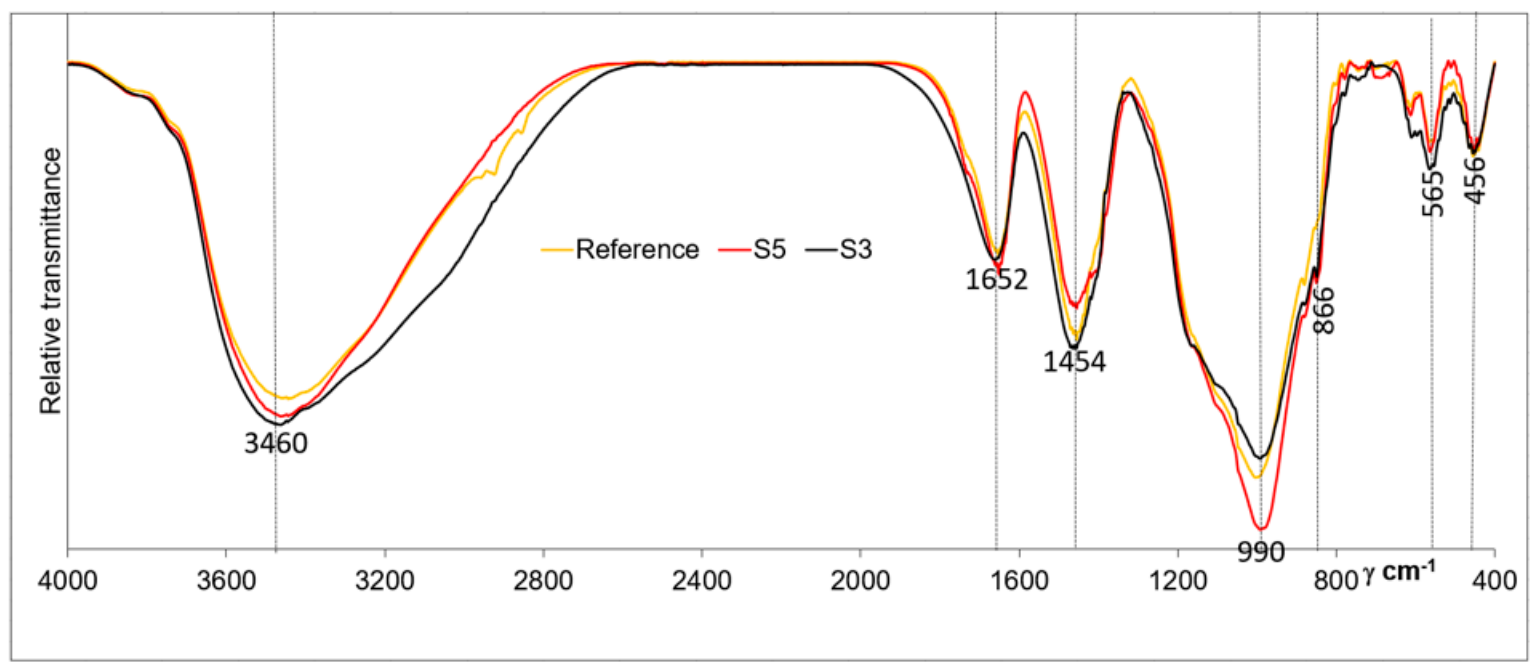

Figure 6. FTIR spectra of hardened cement paste samples containing zeolitic by-product after 28 days of hydration.

Carbonation compounds, such as calcite and calcium hemicarboaluminate hydrate, were detected from the X-ray diffraction patterns (Figure 5). The adsorption bands located at approximately $990 \mathrm{~cm}^{-1}$ are related to the stretching vibration of $\mathrm{Si}-\mathrm{O}-\mathrm{Si}(\mathrm{Al})$ in $\mathrm{C}-\mathrm{S}-$ $\mathrm{H}$ [21]. The S5 sample exhibited the peak with the highest intensity, corresponding to the highest quantity of $\mathrm{C}-\mathrm{S}(\mathrm{A})-\mathrm{H}$ formed during hydration. The $\mathrm{C}-\mathrm{S}(\mathrm{A})-\mathrm{H}$ content is closely related to cement strength (Figure 3 ). The bands at approximately $565 \mathrm{~cm}^{-1}$ correspond to 
the bending vibrations of $\mathrm{Si}-\mathrm{O}$, and the peaks at approximately $456 \mathrm{~cm}^{-1}$ are associated with $\mathrm{O}-\mathrm{Si}-\mathrm{O}$ bond bending vibrations.

The microstructure of the hardened cement paste was observed by scanning electron microscopy (Figure 7). New compounds (hydrates) formed during the hydration process. The zeolitic by-product changed the cement morphology. After 28 days of hydration, columnar aggregates of portlandite embedded in a multi-formed C-S-H structural matrix were observed in the samples. The hydration products detected by the microstructural analysis were confirmed by the X-ray diffraction and FTIR results. Da et al. [13] detected similarly shaped minerals. Therefore, the S5 sample containing the zeolitic by-product with ammonium ions had a more compact microstructure than the reference sample.

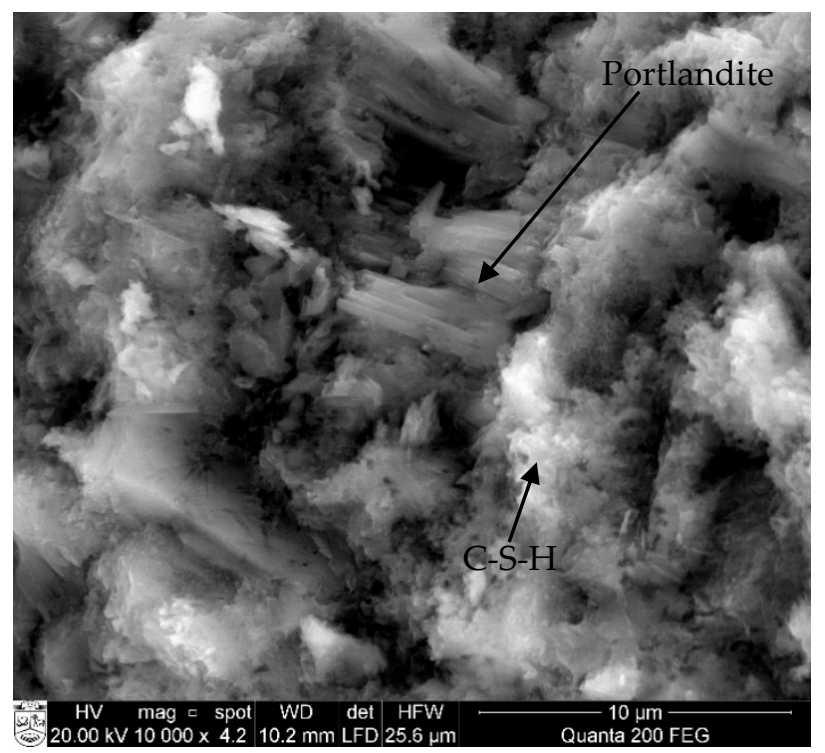

(a)

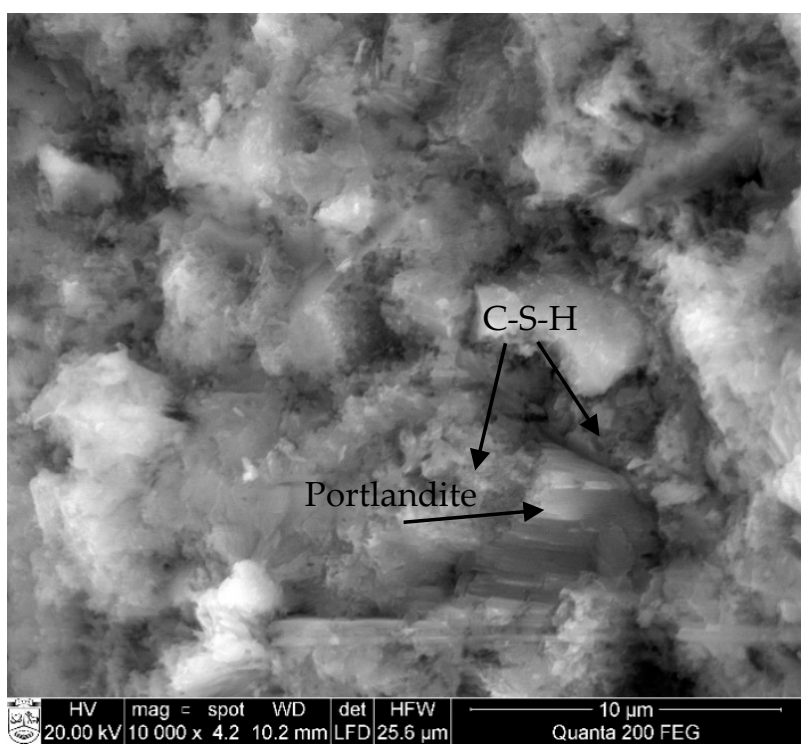

(b)

Figure 7. SEM images of hardened cement paste samples containing zeolitic by-product: (a) reference; (b) S5.

\section{Conclusions}

Replacing a portion of Portland cement with a zeolitic by-product containing ammonium ions significantly changed the main properties of the hardened cement paste, such as compressive strength, density, mineral composition, and microstructure. At early hydration ages (after 7 days), the ammonium chloride in the zeolitic by-product acted as a hydration accelerator, whereas the pozzolanic effect was noted after 28 days of hydration. A small quantity (0.5-3 wt \%) of the zeolitic by-product accelerated hydration by providing nucleation sites for hydrates. The compressive strength of a sample containing $3 \%$ of the zeolitic by-product increased by approximately $17 \%$ after 7 days of hydration. This increase could be explained by the action of ammonium chloride as an accelerator. The increase in the sample strength after 28 days of hydration resulted mainly from the pozzolanic reaction of the zeolitic by-product. A compressive strength of $104 \mathrm{MPa}$ was reached for a sample containing $5 \mathrm{wt} \%$ of the zeolitic by-product, corresponding to an increase of approximately $32 \%$ over that of the reference sample. The results of the XRD and FTIR analyses showed that the same hydration products were obtained as for the hydrated OPC paste. The XRD results showed that an additional hydration product, calcium hemicarboaluminate hydrate, was formed. Both of the aforementioned minerals were associated with the increased compressive strength of samples containing the zeolitic by-product over that of the reference samples. The incorporation of the zeolitic by-product increased the compactness of the cement microstructure. 


\begin{abstract}
Author Contributions: Conceptualization, D.V. and A.M.; methodology, A.K. and A.M.; software, A.K. and A.R.; validation, D.V. and D.B.; investigation, A.M. and D.B.; writing-original draft preparation, D.V. and A.M.; writing-review and editing, D.V. and D.B.; visualization, A.K. and A.R.; supervision, D.V., A.R., and D.B. All authors have read and agreed to the published version of the manuscript.
\end{abstract}

Funding: This research received no external funding.

Institutional Review Board Statement: Not applicable.

Informed Consent Statement: Not applicable.

Conflicts of Interest: The authors declare no conflict of interest.

\title{
References
}

1. Panesar, D.K. Supplementary cementing materials. In Developments in the Formulation and Reinforcement of Concrete, 2nd ed.; Mindess, S., Ed.; Woodhead Publishing: Cambridge, UK, 2019; pp. 55-85.

2. Rahla, K.M.; Mateus, R.; Bragança, L. Comparative sustainability assessment of binary blended concretes using Supplementary Cementitious Materials (SCMs) and Ordinary Portland Cement (OPC). J. Clean. Prod. 2019, 220, 445-459. [CrossRef]

3. Zhao, Y.; Qiu, J.; Xing, J.; Sun, X. Recycling of quarry dust for supplementary cementitious materials in low carbon cement. Constr. Build. Mater. 2020, 237, 117608. [CrossRef]

4. Lu, T.; Li, Z.; Huang, H. Effect of supplementary materials on the autogenous shrinkage of cement paste. Materials 2020, $13,3367$. [CrossRef] [PubMed]

5. Lv, Y.; Ye, G.; De Schutter, G. Investigation on the potential utilization of zeolite as an internal curing agent for autogenous shrinkage mitigation and the effect of modification. Constr. Build. Mater. 2019, 198, 669-676. [CrossRef]

6. Thang, N.C.; Tuan, N.V.; Yang, K.H.; Phung, Q.T. Effect of zeolite on shrinkage and crack resistance of high-performance cement-based concrete. Materials 2020, 13, 3773. [CrossRef] [PubMed]

7. Zhang, G.Z.; Wang, X.Y. Effect of pre-wetted zeolite sands on the autogenous shrinkage and strength of ultra-high-performance concrete. Materials 2020, 13, 2356. [CrossRef] [PubMed]

8. Nagrockiene, D.; Girskas, G. Research into the properties of concrete modified with natural zeolite addition. Constr. Build. Mater. 2016, 113, 964-969. [CrossRef]

9. Rahhal, V.F.; Pavlík, Z.; Tironi, A.; Castellano, C.C.; Trezza, M.A.; Černý, R.; Irassar, E.F. Effect of cement composition on the early hydration of blended cements with natural zeolite. J. Therm. Analys. Calorim. 2017, 128, 721-733. [CrossRef]

10. Lilkov, V.; Rostovsky, I.; Petrov, O. Physical and mechanical characteristics of cement mortars and concretes with addition of clinoptilolite from Beli Plast deposit (Bulgaria), silica fume and fly ash. Clay Miner. 2011, 46, 213-223. [CrossRef]

11. Lilkov, V.; Petrov, O.; Petkova, V.; Petrova, N.; Tzvetanova, Y. Study of the pozzolanic activity and hydration products of cement pastes with addition of natural zeolites. Clay Miner. 2011, 46, 241-250. [CrossRef]

12. Girskas, G.; Skripkiūnas, G.; Šahmenko, G.; Korjakins, A. Durability of concrete containing synthetic zeolite from aluminum fluoride production waste as a supplementary cementitious material. Constr. Build. Mater. 2016, 117, 99-106. [CrossRef]

13. Da, Y.; He, T.; Wang, M.; Shi, C.; Xu, R.; Yang, R. The effect of spent petroleum catalyst powders on the multiple properties in blended cement. Constr. Build. Mater. 2020, 231, 117203. [CrossRef]

14. Allahverdi, A.; Shahrbabaki, M.N.; Ghezelasheghi, M.; Mahinroosta, M. Sulfate resistance of RFCC spent catalyst-blended Portland cement. Boletín Soc. Española Cerámica Vidr. 2019, 58, 103-114. [CrossRef]

15. Su, N.; Fang, H.Y.; Chen, Z.H.; Liu, F.S. Reuse of waste catalysts from petrochemical industries for cement substitution. Cem. Concr. Res. 2000, 30, 1773-1783. [CrossRef]

16. Fu, H.; Li, Y.; Yu, Z.; Shen, J.; Li, J.; Zhang, M.; Ding, T.; Xu, L.; Lee, S.S. Ammonium removal using a calcined natural zeolite modified with sodium nitrate. J. Haz. Mater. 2020, 393, 122481. [CrossRef] [PubMed]

17. Sang, W.; Mei, L.; Hao, S.; Li, D.; Li, X.; Zhang, Q.; Jin, X.; Li, C. Na@La modified zeolite particles for simultaneous removal of ammonia nitrogen and phosphate from rejected water: Performance and mechanism. Water Sci. Technol. 2020, 82, $2975-2989$. [CrossRef]

18. Han, B.; Butterly, C.; Zhang, W.; He, J.Z.; Chen, D. Adsorbent materials for ammonium and ammonia removal: A review. J. Clean. Product. 2020, 283, 124611. [CrossRef]

19. Kotoulas, A.; Agathou, D.; Triantaphyllidou, I.E.; Tatoulis, T.I.; Akratos, C.S.; Tekerlekopoulou, A.G.; Vayenas, D.V. Zeolite as a potential medium for ammonium recovery and second cheese whey treatment. Water 2019, 11, 136. [CrossRef]

20. Qin, L.; Gao, X.; Li, Q. Influences of coal fly ash containing ammonium salts on properties of cement paste. J. Environ. Manag. 2019, 249, 109374. [CrossRef]

21. Lea, F.M. The action of ammonium salts on concrete. Magaz. Concr. Res. 1965, 17, 115-116. [CrossRef]

22. Myrdal, R. Accelerating Admixtures for Concrete. State of the Art; COIN-Concrete Innovation Centre: Trondheim, Norway, 2007.

23. Frybort, S.; Mauritz, R.; Teischinger, A.; Müller, U. Determination of the bond strength of treated wood strands embedded in a cement matrix by means of a pull-out test. Eur. J. Wood Wood Prod. 2009, 68, 407-414. [CrossRef] 
24. Frybort, S.; Mauritz, R.; Teischinger, A.; Müller, U. Cement bonded composites-A mechanical review. BioResources. 2008, 3, 602-626.

25. Bruker. X-ray S8 Tiger WD Series 2 Technical Details. Available online: https://www.bruker.com/products/x-ray-diffractionand-elemental-analysis / x-ray-fluorescence/s8-tiger.html (accessed on 14 December 2020).

26. Bruker. D8 Advance Diffractometer (Bruker AXS) Technical Details. Available online: https://www.bruker.com/products/x-raydiffraction-and-elemental-analysis/x-ray-diffraction/d8-advance.html (accessed on 14 December 2020).

27. CILAS. 1090 Particle Size Analyzer. Available online: https://www.pharmaceuticalonline.com/doc/cilas-1090-particle-sizeanalyzer-0002 (accessed on 14 December 2020).

28. Zeiss. EVO MA and LS Series Scanning Electron Microscopes for Materials Analysis and Life Science; Carl Zeiss SMT: Oberkochen, Germany, 2008. Available online: https:/ / www.scribd.com/document/391914988/EVO-Series-UserGuide (accessed on 1 January 2008).

29. Vaičiukynienė, D.; Mikelionienè, A.; Baltušnikas, A.; Kantautas, A.; Radzevičius, A. Removal of ammonium ion from aqueous solutions by using unmodified and $\mathrm{H}_{2} \mathrm{O}_{2}$-modified zeolitic waste. Sci. Rep. 2020, 10, 1-11. [CrossRef]

30. Velázquez, S.; Monzó, J.; Borrachero, M.V.; Soriano, L.; Payá, J. Evaluation of the pozzolanic activity of spent FCC catalyst/fly ash mixtures in Portland cement pastes. Thermochim. Acta. 2016, 632, 29-36. [CrossRef]

31. García de Lomas, M.; de Rojas, M.S.; Frías, M. Pozzolanic reaction of a spent fluid catalytic cracking catalyst in FCC-cement mortars. J. Therm. Analys. Calorimetr. 2007, 90, 443-447. [CrossRef]

32. Lin, L.; Lei, Z.; Wang, L.; Liu, X.; Zhang, Y.; Wan, C.; Lee, D.J.; Tay, J.H. Adsorption mechanisms of high levels of ammonium onto natural and NaCl-modifed zeolites. Separ. Purif. Technol. 2013, 103, 15-20. [CrossRef]

33. Sadiku, N.A.; Sanusi, A. Wood pre-treatment influence on the hydration of Portland cement in combination with some tropical wood species. Pro Ligno 2014, 10, 3-10.

34. Perraki, T.; Kakali, G.; Kontoleon, F. The effect of natural zeolites on the early hydration of Portland cement. Micropor. Mesopor. Mater. 2003, 61, 205-212. [CrossRef]

35. Perraki, T.; Kontori, E.; Tsivilis, S.; Kakali, G. The effect of zeolite on the properties and hydration of blended cements. Cem. Concr. Comp. 2010, 32, 128-133. [CrossRef]

36. Vaičiukynienė, D.; Pundienè, I.; Kantautas, A.; Augonis, A.; Janavičius, E.; Vaičiukynas, V.; Alobeid, J. Synergistic effect of dry sludge from waste wash water of concrete plants and zeolitic by-product on the properties of ternary blended ordinary Portland cements. J. Clean. Prod. 2020, 244, 118493. [CrossRef]

37. Vaičiukynienè, D.; Grinys, A.; Vaitkevičius, V.; Kantautas, A. Purified waste fcc catalyst as a cement replacement material. Ceram. Silikáty. 2015, 59, 103-108.

38. Cao, Y.; Guo, L.; Chen, B.; Fei, X. Modeling early age hydration kinetics and the hydrated phase of cement paste blended with chloride and sulfate. Constr. Build. Mater. 2020, 261, 120537. [CrossRef]

39. Lothenbach, B.; Scrivener, K.; Hooton, R.D. Supplementary cementitious materials. Cem. Concr. Res. 2011, 41, 1244-1256. [CrossRef]

40. Díaz, J.E.; de Gutierrez, R.M.; Torres, J. Blended cement containing fluid catalytic cracking catalyst residue (FCC): Hydration and paste microstructure. Rev. Ing. Constr. 2013, 28, 141-154.

41. Kocak, Y.; Tasc1, E.; Kaya, U. The effect of using natural zeolite on the properties and hydration characteristics of blended cements. Constr. Build. Mater. 2013, 47, 720-727. [CrossRef]

42. Jose, A.; Nivitha, M.R.; Krishnan, J.M.; Robinson, R.G. Characterization of cement stabilized pond ash using FTIR spectroscopy. Constr. Build. Mater. 2020, 263, 120136. [CrossRef] 